\title{
MENGENANG KOTA HILANG. KEMBALINYA HARMONI GLAGAHARUM SIDOARJO
}

\author{
Shaellina Alfath Mauludy ${ }^{1)}$, Sutarki Sutisna ${ }^{2)}$ \\ 1)Program Studi S1 Arsitektur, Fakultas Teknik, Universitas Tarumanagara, shaellina.am@gmail.com \\ 2) Program Studi S1 Arsitektur, Fakultas Teknik, Universitas Tarumanagara, sutarkis@gmail.com
}

\begin{abstract}
Abstrak
Lumpur Lapindo merupakan bencana alam akibat ulah manusia yang membawa kesedihan dan keterpurukan bagi korban dan warga sekitar, kisah mereka yang kini semakin hari semakin terlupakan. Desa Glagaharum dipilih karena kisah warganya sebagai "Penghuni Terakhir" yang memilih bertahan pada desanya yang bersebelahan dengan tanggul lumpur, memilih bertahan untuk menjaga kenangan kehidupan mereka yang tumbuh besar di desa ini meski mata pencahariannya hilang dalam Lumpur Lapindo. Proyek ini dibuat untuk membangun kenangan kejadian bencana alam Lumpur Lapindo sebagai pembelajaran akibat ulah manusia, mengenang perjuangan para korban bencana dalam memperjuangkan hak dan keharmonian yang mereka dulu dapatkan. Menggunakan metode narasi yang dilatar belakangi oleh cerita pendek R. Giryadi "Mengenang Kota Hilang" sebagai alur program ruang yang tercipta pada Area Mengenang. Lalu, penggunaan Teori Parktik Sosial oleh Pierre-Felix Bourdieu untuk mengembalikan harmoni sosial, menciptakan Area Ekonomi dan Area Sosial-Budaya sebagai ruang warga untuk berkumpul, membuat dan menjual karya seni keramik dari Lumpur Lapindo yang menjadi mata pencaharian baru warga setempat. Dan adanya penyediaan filtrasi lumpur dan air bersih yang dapat digunakan oleh warga sekitar. Proyek ini memiliki 4 dari 6 parameter "Melampaui Ekologi" yaitu, Adaptation, Resilience, Sustainable Digital, dan Context. Proyek yang menjadi harapan sebagai tempat tujuan akhir dari semua permasalahan yang dirasakan oleh para korban bencana, dan sebagai tempat yang dapat selalu menjaga kenangannya.
\end{abstract}

Kata kunci: Melampaui Ekologi; Kota Hilang; Lumpur Lapindo; Mengenang; Sidoarjo.

\begin{abstract}
The Lapindo Mudflow is an environmental disaster caused by human activities that brings sorrow and misery to the victims and local residents, their story is now starting to be forgotten. Glagaharum village was chosen as the site for this project, because of the residents stories as the "Last Inhabitants" who chose to stay firm in their village alongside with the mud embankment, they chose to survive to preserve the memories of their lives in that village even though their livelihood were lost in the Lapindo Mudflow. This project aims to build awareness of the Lapindo Mudflow disaster as a lesson learned from human activities, remembering the struggle of the disaster victims in fighting for the rights and harmony that they used to get. Using narrative method inspired by R. Giryadi's "Mengenang Kota Hilang" as the spatial program flow created in the Reminiscing Area. And then, using Social Practice Theory by Pierre-Felix Bourdieu to restore social harmony, that created Economy Area and Socio-Cultural Area as a space for residents to gather, make and sell ceramic art from Lapindo Mudflow which became the new livelihood of local residents. And the provision of mud filtration and clean water that can be used by local residents. This project has 4 out of 6 parameters "Beyond Ecology" namely Adaptation, Resilience, Sustainable Digital, and Context. A project that becomes hope as the final destination of all the problems felt by disaster victims, and as a place where they can always keep their memories.
\end{abstract}

Keywords: Beyond Ecology; Lapindo Mudflow; Reminiscing; Sidoarjo; The Lost City. 


\section{PENDAHULUAN}

\section{Latar Belakang}

Ekologi memiliki keterhubungan dan keharmonisannya antara satu dengan yang lainya. Lumpur panas Lapindo di Sidoarjo merupakan salah satu bencana alam yang terjadi akibat kelalaian manusia dan mengganggu keharmonisan lingkungan disekitarnya. Bencana ini menenggelamkan kawasan permukiman, pertanian dan peridustrian di tiga kecamatan disekitar semburan yang mengakibatkan kelumpuhan dan kerusakan alam disekitarnya. Pencemaran air pada lingkungan sekitar disebabkan dari kandungan lumpur yang memiliki kadar logam yang tinggi. Lumpur Lapindo juga menyebabkan adanya pencemaran udara disekitar kawasan, bau belerang yang tak sedap dan kadar hidrokarbon yang tinggi dari uap panas yang dikeluarkan. Dampak sosial ekonomi juga sangat dirasakan oleh masyarakat setempat terutama masyarakat Desa Glagaharum, Kecamatan Porong, Sidoarjo. Sebagian warga kehilangan tempat tinggal dan pekerjaannya, sebagian dari yang lainnya terpaksa bertahan dan harus mencari pekerjaan ditempat yang lebih jauh dari area tinggalnya.

".... Bertapalah di gunung batinmu. Jangan datang ke kotaku. Kotaku, kini hilang. Kini yang tertinggal hanya kenangan dan harapan-harapan...." Merupakan sepenggal kalimat dari cerita pendek yang ditulis oleh R. Giryadi tentang "Mengenang Kota Hilang", cerita tentang isi hati para masyarakat Sidoarjo yang terkena dampak bencana semburan lumpur panas Lapindo. Kisah kenangan keharmonian mereka yang kini mulai terlupakan bersama dengan lumpur yang semakin meratakan, menenggelamkan kota mereka.

Akankah warga Desa Glagaharum, Sidoarjo dapat mengambil keharmonisannya kembali dengan memanfaatkan Lumpur Lapindo sebagai sumber daya alam mereka? Mengembalikan ekonomi warga yang dulu sempat terpuruk dengan menyediakan lahan mata pencaharian baru bagi warga sekitar serta menyediakan tempat area sosial - budaya untuk membangun ikatan sosial dan mengembalikan budaya yang hilang akibat Lumpur Lapindo. Membangun kenangan kesedihan, ketakutan dan kehilangan para korban atas kejadian Lumpur Lapindo yang menggores luka mereka, Agar kenangan ini tak hilang dan hanya menjadi legenda masa lalu di masa depan.

\section{Rumusan Permasalahan}

Berdasarkan latar belakang diatas, rumusan masalah dalam proyek ini adalah desain arsitektur seperti apa yang dapat membangun suasana ruang, sehingga dapat mengembalikan kenangan dan keharmonisan Sidoarjo dengan pemanfaatan sumber daya alam dari lumpur lapindo.

\section{Tujuan}

Dalam mendesain proyek ini bertujuan untuk membangun suatu kawasan yang terkena dampak oleh Lumpur Lapindo kembali kepada keharmonisannya. Melalui peningkatan ekonomi dan mata pencaharian baru warga setempat, membangun ikatan sosial dalam aktivitas kebudayaan, serta mengembalikan kenangan atas kesedihan dan perjuangan korban Lumpur Lapindo.

\section{KAJIAN LITERATUR}

\section{Ekologi dan Arsitektur}

Ekologi adalah ilmu yang mempelajari interaksi antara organisme dengan lingkungan lainnya. Ekologi berasal dari kata Yunani oikos ("habitat") dan logos ("ilmu"). Ekologi memiliki arti sebagai pengetahuan yang mempelajari interaksi antar makhluk hidup serta interaksi antara makhluk hidup dan lingkungannya. Istilah ekologi pertama kali dikemukakan oleh Ernst Haeckel (1834 - 1914) (Frick \& Suskiyatno, 1998).

Dalam ekologi, ilmu tentang sistem kehidupan dan hubungannya adalah keseluruhannya yang terintegrasi oleh sifat-sifat yang muncul dari hubungan antara bagian-bagian individualnya. Setiap bagian mencerminkan keseluruhan tetapi keseluruhannya selalu berbeda dari sekadar jumlah bagian-bagiannya. Melalui definisi sistem kehidupan ini, kita dapat mulai 
mengidentifikasi perbedaan utama antara sistem biotik dan abiotik. Dalam sistem abiotik "tidak hidup" (dalam kasus - bangunan) komponen bersama-sama membentuk kesuluruhan melalui struktur hierarki konstruksi - setiap bagian dari sistem memiliki fungsinya sendiri dan dibangun secara khusus untuk melakukan fungsi ini.

Ilmu tentang sistem kehidupan telah mempengaruhi desain arsitektur dalam berbagai cara, meskipun hasilnya menunjukan bahwa arsitek dan desainer tidak benar-benar memahami bagaimana fungsi sistem kehidupan, melainkan mencoba meminjam ide-ide baru dari sains dan ekologi dan mengekspresikan dalam arsitektur dengan cara yang dangkal (Dinur, 2007).

\section{Prinsip Etika Ekologi}

Pada prinsip Etika Ekologi adalah semua bentuk kehidupan memiliki nilai bawaan dan karena itu memiliki hak untuk hidup dan hak untuk berkembang. Etika Ekologi dapat dibedakan menjadi etika pelestarian dan etika pemeliharaan. Etika pelestarian adalah etika yang menekankan pada mengusahakan pelestarian alam untuk kepentingan manusia, sedangkan etika pemeliharaan dimaksudkan untuk mendukung usaha pemeliharaan lingkungan untuk kepentingan semua mahluk yaitu usaha manusia untuk menciptakan keharmonisan kepada alam dan lingkungannya (Sulistiono, 2013).

Beberapa prinsip yang dapat menjadi pegangan dan tuntunan bagi arsitek dalam berhadapan dengan alam, yaitu: 1. Sikap Hormat terhadap Alam (Respect for Nature); 2. Sikap Tanggung Jawab (Moral Responsibility for Nature); 3. Sikap Solidaritas Kosmis (Cosmic Solidarity); 4. Sikap Kasih Sayang dan Kepedulian terhadap Alam (Carring for Nature); 5. Prinsip tidak menimbulkan kerusakan (no harm principle). (Keraf, 2010)

\section{Melampaui Ekologi}

Melampaui Ekologi adalah sebuah kondisi ekosistem dengan kondisi formasi sosialnya yang mengalami kondisi kecepatan dan percepatan. Pada titik ini, Kecepatan menjadi jantung dunia keseharian dan Ekosistem disekitar kita mengalami 'pemadatan waktu' sebagai konsekuensi dari percepatan kehidupan (Susanto, 2021).

Manusia sebagai rantai kehidupan teratas dan dengan akal pikiran mereka yang dapat melampaui semua makhluk hidup. Debgan pengembangan bermacam-macam teknologi yang ditujuan untuk menyeimbangkan kehidupan pada alam mereka, karena yang mereka sadai bahwa manusia tak hidup sendiri. Teknologi yang dapat bersahabat dengan alam inilah yang disebut dengan melampaui ekologi itu sendiri. Dimana inovasi dan teknologi tercipta untuk sebuah keharmonisan dalam ekosistem. Terdapat 6 parameter arsitektur untuk menuju 'Melampaui Ekologi', yaitu: 1. Energy and Emission; 2. Adaptation; 3. Resilience; 4. Sustainable Digital; 5. New Technology; 6. Context. (Susanto, 2021)

\section{Harmoni Sosial}

Dalam Kamus Besar Bahasa Indonesia harmoni berarti selaras atau serasi, sedangkan sosial berarti berkenaan dengan masyarakat, mengenai masyarakat, atau suka memperhatikan kepentingan umum. Harmoni sosial adalah kondisi dimana individu hidup sejalan dan serasi dengan tujuan masyarakatnya (Qodratilah, 2011).

Harmoni Sosial juga terjadi dalam masyarakat yang ditandai dengan solidaritas (Mulya, 2015), dimana adanya keseimbangan dalam sebuah kehidupan yang selalu diimpikan oleh semua masyarakat dalam kehidupannya.

\section{Teori Praktik Sosial}

Keharmonian dalam Kamus Besar Bahasa Indonesia berarti keadaan yang harmonis (KBBI Daring, 2016). Untuk memperoleh suatu keharmonian dalam suatu tempat penggunaan Teori Praktik Sosial yang diciptakan oleh Pierre-Felix Bourdieu merupakan salah satu upaya masyarakat atau individu dalam mengatasi masalah kehidupan sosialnya.Teori Praktik Sosial 
memiliki beberapa konsep penting yaitu, habitus, ranah, kekerasan simbolik, modal, dan strategi. Habiatus, modal dan ranah memiliki peran yang berlaku dalam praktik kehidupan masing-masing aktor (masyarakat / individu). Melalui rumus generatif dengan persamaan: (Habitus X Modal) + Ranah = Praktik. Adanya relasi aktor dengan habitus yang melibatkan modal dan ranah. Habitus adalah hasil pembelajaran lewat pengasuhan, aktifitas bermain dan pendidikan (Lubis, 2014)

Konsep habiatus secara singkat adalah hasil internalisasi struktur dunia sosial. Habiatus merupakan produk sejarah yang terbentuk setelah manusia lahir dan berinteraksi dengan masyarakat dalam ruang dan waktu tertentu. Ranah dalam teori ini yakni, arena sosial dimana aktor berjuang dan bersaing mengejar sumberdaya atau kekuatan simbolis yang didambakan. Tujuannya adalah memastikan perbedaan yang menjamin status aktor sosial (Lubis, 2014).

\section{Arsitektur dan Kenangan}

Hubungan simbiosis antara arsitektur dengan kenangan adalah persembahan dari penggabungan keduanya untuk menciptakan hubungan dalam ruang dan waktu; fragmentasi antara masakini dan masalalu menghilang sebagai satu tempat, memalui penggambaran keseluruhan satu dengan lainnya. Arsitektur dan kenangan mempunyai hubungan antara satu dengan lainnya dalam penggunaan persepsi dan empati dengan penggambaran untuk mengingat kembali suatu tempat, keterhubungan suatu tempat dengan lainnya, dan dengan cara ini mungkin dapat menjelaskan waktu dalam istilah yang nyata. Untuk kenangan, arsitektur merupakan simbolisasi dalam titik referensi dalam waktu- sebuah proscenium di mana pengalaman dapat diingat kembali; dalam arsitektur, kenangan memperlihatkan esensi bentuk yang memperbolehkan lingkungan binaan untuk membentuk pemahaman spasial manusia. (Hopkins, 1996)

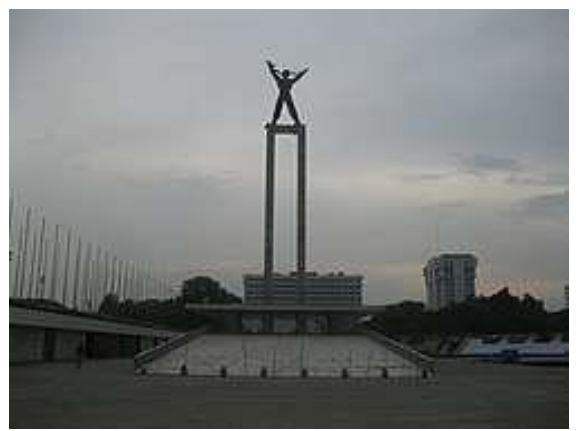

Gambar 1 : Monumen Pembebasan Irian Barat Sumber: Mikhael, 2018

Selanjutnya, program dapat berekspresi dalam mengungkapkan kenangan, melalui bentuk arsitektur dan komponennya. Lalu, sebagai representasi sebuah tempat, kenangan dan arsitektur memiliki ketergantungan dengan tapaknya. Pada akhirnya tempat ini, ketika terorganisasi dalam hubungannya dengan tempat lain di dalam kota, sehingga kota dapat dibaca memlalui citra yang dapat diingat, dari keterhubungan yang melampaui batas. (Hopkins, 1996).

\section{Fenomena Lumpur Lapindo}

Banjir lumpur panas Sidoarjo, juga dikenal dengan sebutan Lumpur Lapindo (Lula) atau Lumpur Sidoarjo (Lusi), adalah peristiwa menyemburnya lumpur panas di lokasi pengeboran Lapindo Brantas Inc. di Dusun Balongnongo Desa Renokenongo, Kecamatan Porong, Kabupaten Sidoarjo, Jawa Timur, Indonesia, sejak tanggal 29 Mei 2006 dan merupakan peristiwa alam yang terjadi akibat kesalahan prosedur pengeboran oleh PT. Lapindo Brantas (Wikipedia: Banjir lumpur panas Sidoarjo, 2021). Semburan lumpur panas ini menyebabkan tergenangnya kawasan permukiman, pertanian, dan perindustrian di tiga kecamatan di sekitarnya, sehingga mempengaruhi aktivitas perekonomian di Jawa Timur. Kawasan sekitar mengalami adanya 
pencemaran air dari material lumpur yang memiliki kadar logam yang tinggi dan pencemaran udara dari uap panas semburan lumpur yang memiliki kadar hidrokarbon yang tinggi. Tak hanya dampak biotik yang dirasakan tetapi dampak abiotik juga sangat dirasakan oleh masyarakat. Mereka mengalami kemunduran pranata sosial ekonomi dan rusaknya tatanan sosial karena hilangnya pekerjaan dan tempat tinggal mereka.

Pengalihan lumpur ke Sungai Porong yang hilirnya menuju laut, sebagai "Tanggul ke-2 Lumpur Sidoarjo" adalah sebagai solusi untuk mencegah bocornya tanggul yang sudah pernah terjadi sebelumnya. Aksi yang dilakukan ini kembali berdampak pada lingkungan yang lainnya. Endapan lumpur pada Sungai Porong menyebabkan kawasan disekitar sungai menjadi rawan banjir, dan rusaknya ekosistem biota air (Wikipedia: Banjir lumpur panas Sidoarjo, 2021).

Masyarakat sekitar yang masih bertahan mencoba memanfaatkan sumber daya alam yang kini ada yaitu, pemanfaatan Lumpur Lapindo. Dengan manfaat Lumpur Lapindo adalah sebagai berikut: Pemanfaatan sumber daya listrik (Geothermal), Pembuatan kerajinan keramik, Pembuatan bahan bangunan seperti Batu Bata dan pembuatan baterai.

\section{METODE}

Metode yang digunakan untuk mencapai program tujuan proyek yang dapat mencakup masa lalu, masa sekarang, dan masa depan, dengan menggunakan narasi baru yang disusun berdasarkan naratif cerita 'Mengenang Kota Hilang' dan timeline bencana Lumpur Lapindo sebagai Area Mengenang. Selain itu metode penggunaan Teori Praktik Sosial yang akan menghubungkan narasi dengan aktivitas dari area dan program ruang yang terbentuk sebagai Area Ekonomi dan Area Sosial-Budaya.

\section{Naratif 'Mengenang Kota Hilang'}

Pendekatan naratif merupakan pendekatan yang digunakan untuk membuat pengguna bangunan merasa terlibat langsung dengan suasana ruang pada bangunan. Aspek untuk membentuk narasi itu sendiri terdiri dari plot cerita dan perasaan pengguna dalam merasakan keruangan, dua hal tersebut yang dapat diaplikasikan ke dalam objek rancangan (Maulidina, 2016). Untuk memahami suasana apa yang ingin disampaikan kepada pengguna atau pengunjung maka perlu pemahaman terlebih dahulu bagaimana plot dari cerita narasi serta pengaplikasiannya dalam arsitektur. Objek rancang yang menjadi hasil akhir rancangan adalah proyek yang dapat merasakan suasana arsitektural mulai dari suasana mencekam sampai suasana yang dapat mengembalikan kebahagiaan yang disusun dari narasi cerita 'Mengenang Kota Hilang' oleh R. Giryadi.

Cerita pendek 'Mengenang Kota Hilang' oleh R Giryadi, merupakan cerpen sindiran tentang tatanan sosial masyarakat Kota Sidoarjo yang kini tenggelam oleh Lumpur Lapindo (Giryadi, 2012). Dalam cerita ini, R. Giryadi banyak menyisipkan konsep ruang yang nyata dan ruang yang fantasi. Sindiran tentang tatanan sosial masyarakat tentang kota yang "Hilang", merupakan citra Kota Sidoarjo yang semakin lama semakin pudar. Dengan kenyataan bahwa tidak ada pihak yang bertanggungjawab terhadap lumpur yang merendam kota tersebut. Sehingga kini derita warga Kota Sidoarjo ikut terlupakan hari demi hari. Dalam kutipan cerpen ini, untuk bertahan pada Lumpur Lapindo harus mengkantongkan sekarung nyawa, melawan jalan maut, melawan pencemaran air yang diakibatkan oleh Lumpur Lapindo (Saraswati, 2019). 


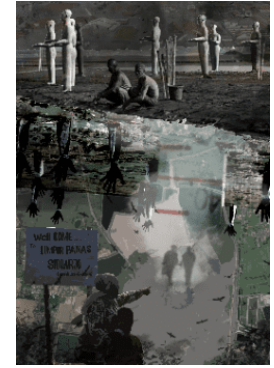

Gambar 2 : Poster Mengenang Kota Hilang Sumber: Dokumen Penulis, 2021

Dengan isi cerita pendek ini kita dapat merasakan penderitaan para korban Lumpur Lapindo, kisah hidup mereka dan perjuangannya hanyalah sebuah kenangan yang semakin lama terkubur tenggelam dalam kolam lumpur.

\section{Plot Naratif}

Penentuan plot naratif dibuat dengan menggabungkan 6 plot narasi dari cerita 'Mengenang Kota Hilang' dan 4 plot timeline fenomena Lumpur Lapindo. Dari penggabungan alur cerita dan timeline fenomena, 10 plot narasi tersebut dan disusun menjadi alur program pada proyek yaitu: Tiang Kebohongan, Plaza Melangkah, Atrium Cahaya Harapan, Ruang Masa Lalu, Semburan Lumpur, Ruang Labirin, Ruang Gelap Retorika, Jalan Maut, Bertahan Hidup dan Menuju Keharmonian

\section{Teori Praktik Sosial}

Penggunaan rumus dalam Teori Praktik Sosial ini untuk menentukan aktivitas-aktivitas yang akan dihidupkan dalam program ruang, dengan rumus Teori Praktik Sosial yaitu (Habiatus $\mathrm{x}$ Modal) + Ranah. Dalam habiatus, modal yang harus tercipta adalah aktivitas dari segi modal ekonomi seperti aktivitas jual-beli, dari segi modal sosial aktivitas yang dapat menimbulkan interaksi serta pembelajaran dan dari segi modal budaya aktivitas yang ada merupakan aktivitas pentas seni tradisional setempat ataupun festival tahunan yang ada. Lalu pada ranah yang ada pada proyek ini adalah pengaruh tempat kepada manusianya, yaitu Desa Glagaharum yang memerlukan area filtrasi air untuk warganya dan Lumpur Lapindo yang dapat dimanfaatkan sebagai bahan kerajinan seni keramik.

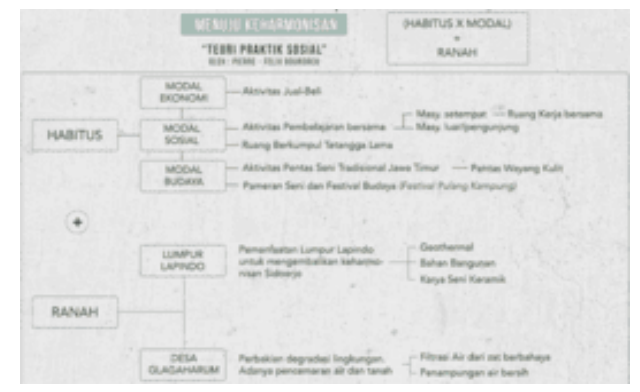

Gambar 3 : Diagram Teori Praktik Sosial Sumber: Dokumen Penulis, 2021

\section{DISKUSI DAN HASIL}

\section{Lokasi Perancangan}

Kriteria pemilihan tapak yang dituju untuk area perancangan pada proyek ini adalah, dekat dengan tanggul lumpur dan dekat dengan area pemukiman yang masih bertahan disekitar kawasan untuk pemanfaatan peningkatan area aktivitas ekonomi warga setempat.

Desa Glagaharum, Kecamatan Porong, Sidoarjo, Jawa Timur merupakan desa yang termasuk area terdampak bencana Lumpur Lapindo. Warga Desa Glagaharum yang terkenal sebagai "Para 
Penghuni Terakhir", warga memilih bertahan dengan degradasi lingkungan yang disebabkan oleh lumpur lapindo itu sendiri. Rata-rata warga yang tinggal bertahan adalah warga yang sudah berumur, memiliki keterikatan yang kuat dengan desa sebagai tempat kehidupannya dari lahir hingga berkeluarga, mereka tumbuh dan hidup dalam lingkungan masyarakat desa Glagaharum. Takutnya masyarakat akan penyesuaian kehidupan baru di daerah lain dan pertimbangan kondisi perekonomian dsb.

Tapak yang terpilih berada di kawasan Desa Glagaharum dan diatas tanggul Lumpur Lapindo di titik 88. Tapak ini memiliki 2 area yang berbeda, sebagian berada diatas tanggul Lumpur Lapindo setinggi $16 \mathrm{~m}$ dan area sebagiannya berada pada tanah kosong bekas terdampak Lumpur Lapindo. Dengan luas tapak sebesar $39.850 \mathrm{~m} 2$ ini tidak memiliki ketentuan peraturan pembangunan resmi, karena area tapak sudah diambil alik oleh PT. Lapindo.
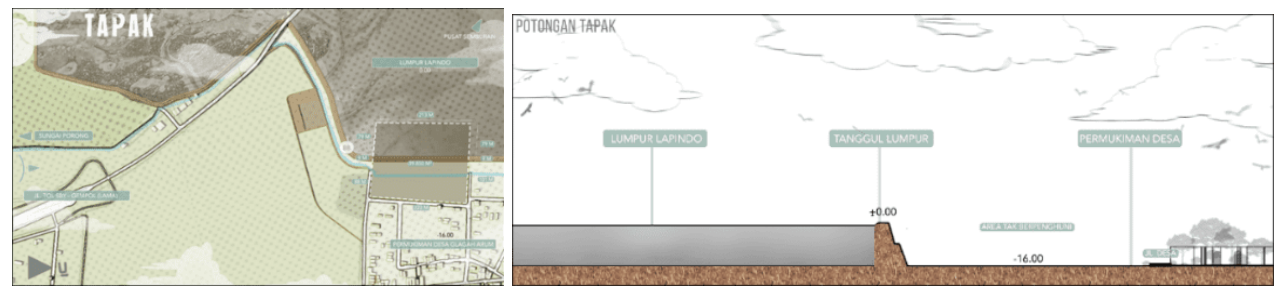

Gambar 4 dan 5: Lokasi Tapak dan Potongan Tapak Sumber: Dokumen Penulis, 2021

\section{Analisis Tapak}

Akses

Akses yang ada untuk menuju tapak dari jl. Tol lama Porong-Sidoarjo sepanjang $5 \mathrm{~km}$ dan melewati area permukiman warga desa. Sehingga untuk kenyamanan warga desa agar pengunjung publik yang masuk ke dalam tapak tidak mengganggu kawasan permukiman, diusulkan membuat akses baru dari jl. Tol lama Porong-Sidoarjo. Jalan yang sudah mati tak terpakai digunakan kembali dan sebagai pengembalian kenangan para pengunjung, bahwa dulu jalur tol ini membawa kemajuan untuk kawasan sekitar.

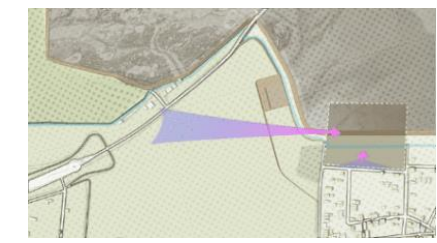

Gambar 6: Analisis Akses Tapak

Sumber: Dokumen Penulis, 2021

Zona Lumpur

Sebagian area tapak yang berada diatas tanggul lumpur setinggi $16 \mathrm{~m}$ difungsikan sebagai area mengenang dan area yang menunjukan bahwa warga sudah dapat berharmonisasi dengan lumpur, serta tempat filtrasi air dengan lumpur dan sebagai tempat kolam tampung.

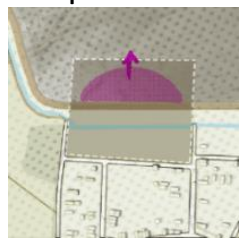

Gambar 7: Analisis Zona Lumpur Tapak

Sumber: Dokumen Penulis, 2021 
Zona Warga

Area tapak yang berada di permukiman desa di fungsikan sebagai area menuju keharmonisasian. Bagaimana warga berjuang untuk mencapai keharmoniannya, dan sebagai area tempat sosial-budaya. Tempat mereka berkumpul dan bersikusi, dan menjalankan aktifitas kebudayaan yang hilang akibat Lumpur Lapindo.

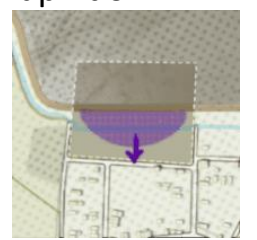

Gambar 8: Analisis Zona Warga Tapak

Sumber: Dokumen Penulis, 2021

Matahari - Angin

Matahari, area yang lebih rendah berada di timur cahaya pagi menerangkan area warga dan ketika sore hari panas matahari terhalang oleh bangunan yang berada di atas tanggul. Sehingga area warga dapat terasa sejuk.

Pada bangunan utama mengenang, di sisi atas penempatan kaca skylight berada di setiap sisi bangunan untuk mendapatkan atau menyerap cahaya matahari lebih banyak dan dapat membiasi R. Atrium Cahaya Harapan di lantai dasar.

Angin pada tapak berhembus dari arah barat, dimana barat merupakan area lumpur pada bagian tapak. Guna mengurangi bau busuk dari Lumpur Lapindo yang mengarah pada tapak posisi gubahan diatas tanggul melebar atau membuka diarah timur, sehingga angin dari arah barat yang membawa bau busuk ke dalam tapak berkurang.
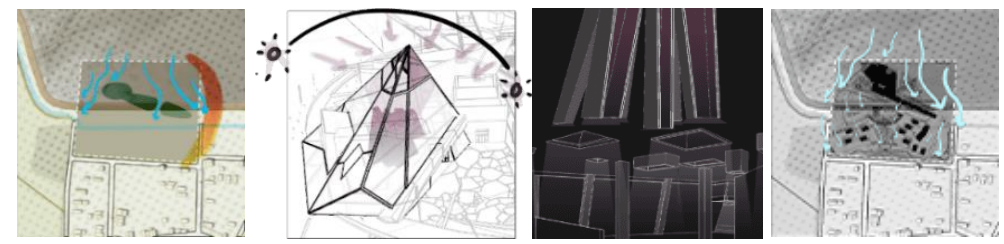

Gambar 9: Analisis Matahari - Angin Tapak

Sumber: Dokumen Penulis, 2021

View

View Timur tapak apabila bangunan berada diatas tanggul lumpur dapat melihat semburan lumpur lapindo. Dan view Barat merupakan area permukan Desa Glagaharum.

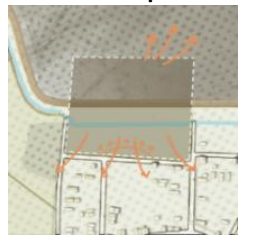

Gambar 10: Analisis View Tapak

Sumber: Dokumen Penulis, 2021

\section{Lingkungan}

Dengan adanya 2 area yang berbeda pada tapak, serta perbedaan level yang jauh yaitu $16 \mathrm{~m}$ maka usulan untuk melandaikan 2 area dengan mengisi tapak yang lebih rendah. Menyatukan 2 area yang berbeda.

Aliran air yang mengarah ke Sungai Porong dibentuk ulang dengan adanya penambahan isi tapak, aliran air yang terbentuk mengikuti outline penambahan isi tapak dan di bentuk secara natural seperti sungai kecil. Aliran air ini juga bersumber dari hasil filtrasi air yang ada di dalam tapak, mengalir ke area yang lebih rendah dan mengikuti aliran menuju ke Sungai Porong. 


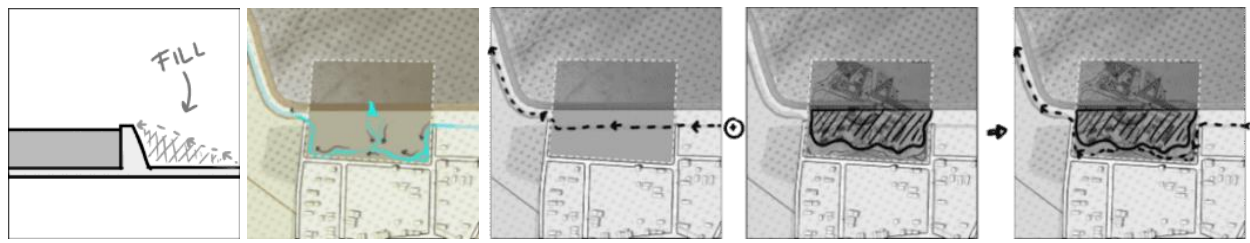

Gambar 11: Analisis Lingkungan Tapak

Sumber: Dokumen Penulis, 2021

\section{Program}

Berdasarkan permasalahan dan penyelesaian dengan metode yang digunakan dari 3 area yang tercipta, program ruang yang dimiliki disetiap area adalah sebagai berikut:

\section{Area Mengenang}

Tiang Kebohongan, Plaza Melangkah, Atrium Cahaya Harapan, Ruang Masalalu, Ruang Semburan, Ruang Labirin, Ruang Gelap Retorika, Jalan Maut.

2. Area Ekonomi

Kios Seni Keramik, Kios Kuliner, Ruang Kerja Bersama, Ruang Diskusi Warga.

3. Area Sosial-Budaya

Ampiteater (Stage), Ruang Serbaguna, Galeri Seni Keramik, Plataran View Semburan Lumpur.

\section{Konsep}

Proyek ini didesain untuk membangun kenangan para korban Lumpur Lapindo, bagaimana kenangan tersebut dapat tersampaikan melalui suasana keruangan. Kenangan kesedihan para korban yang telah kehilangan kehidupannya, dan ketakutan kecemasan para warga yang masih bertahan dan tinggal di sekitar tanggul Lumpur Lapindo. Membawa suasana yang kaku dan mencekam.

\section{Sequence Narasi}

Sequence narasi ini di susun dari plot cerita pendek 'Mengenang Kota Hilang' yang digabungkan dengan timeline fenomena lumpur lapindo adalah sebagai berikut:
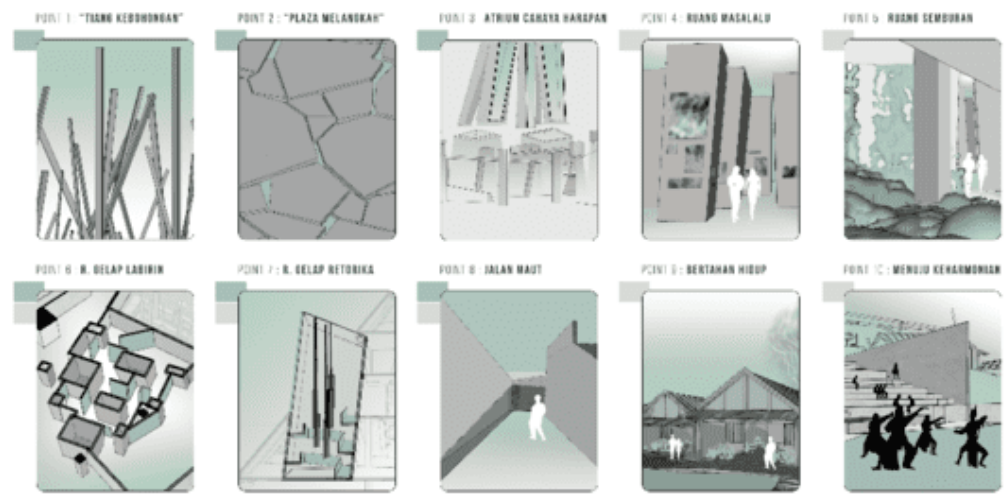

Gambar 12: Sequence Narasi

Sumber: Dokumen Penulis, 2021

1. Tiang Kebohongan

Kisah kota yang tertutup oleh kebohongan-kebohongan pemerintah. "Tak ada kebenaran di kota kami.."

2. Plaza Melangkah

Saat datang kekotaku hati-hatilah dalam melangkah bila tak ingin menjadi lintah. "Langkah itu akan menentukan nasibmu"

3. Atrium Cahaya Harapan

Para korban lapindo hanya bisa berdoa untuk kelanjutan hidupnya. "Tak ada harapan, 
kecuali harapan untuk mati"

4. Ruang Masalalu

Ruang dokumentasi keharmonian para korban lapindo sebelum bencana mengambil kehidupan mereka. "Dulu ketika aku masih mempunyai mimpi"

5. Ruang Semburan

Ruang dengan instalasi keramik yang dibentuk seperti lumpur yang keluar dari dalam lantai dan dinding. "Lumpur keluar dari perut bumi dan menenggelamkan ribuan mimpi"

6. Ruang Labirin

Menuju kota yang hilang melewati jalan labirin yang gelap. "Kau tau jalan yang bercabang itu tak akan sampai ke kotaku"

7. Ruang Gelap Retorika

Mereka yang tinggal bertahan telah mereka2 dan mengais2 kata terang yang gelap maknanya. "Kota yang tenggelam tak hanya dalam lumpur tetapi dalam timbunan retorika"

8. Jalan Maut

Untuk melewati jalan ini siapkanlah hati dan jiwamu. "Kekotaku kini hanya ada satu jalan. Jalan Maut"

9. Bertahan Hidup

Korban terpaksa bertahan menggunakan sumber daya alam yang ada. Lumpur. "Lumpur yang bermanfaat meskipun mengandung tangisan di dalamnya.

10.Menuju Keharmonian

Sebagai tujuan akhir permasalahan yang ada tempat mereka mengenang dan kebangkitan ekonomi-sosial-budaya yang ikut tenggelam dalam lumpur.

\section{Strategi Desain}

Komposisi Massa

Strategi Komposisi Massa pada proyek ini memiliki 4 step yang dilalui, yaitu:

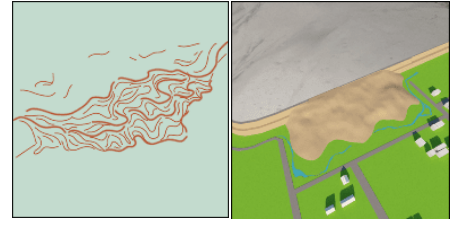

Gambar 13: Tanggul Jebol Sumber: Dokumen Penulis, 2021

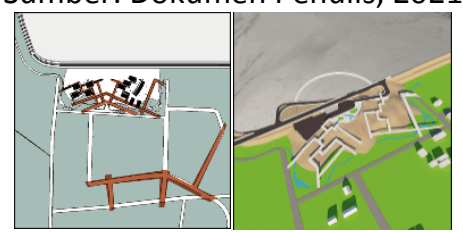

Gambar 15: Jalan Setapak

Sumber: Dokumen Penulis, 2021

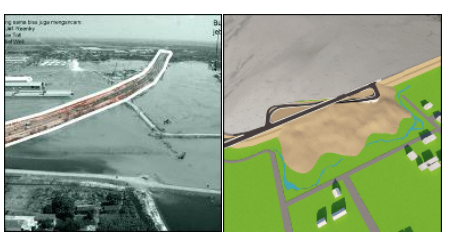

Gambar 14: Akses Baru

Sumber: Dokumen Penulis, 2021

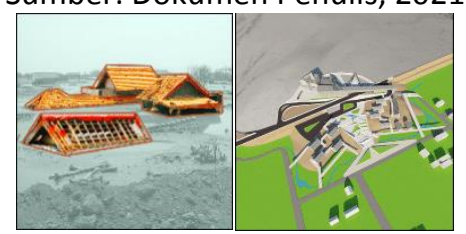

Gambar 16: Genting Tenggelam

Sumber: Dokumen Penulis, 2021

- Tanggul Jebol

Fill tapak yang berpola sepeti lumpur yang keluar dari tanggul. Menggambarkan Ketakutan para warga yang bertahan tinggal berdampingan dengan tanggul lumpur, dihantui dengan kecemasan terulang kembali tanggul yang akan jebol itu.

- Akses Baru

Jalan layang dari jl. Tol lama Porong-Sidoarjo. Menuju tujuan akhir pada proyek "Mengenang Kota Hilang". Akses ini untuk memunculkan awal kenangan melalui akses Jl. Tol lama yang kini menjadi area mati. Kenangan bahwa dulu jalan ini membawa keharmonisan bagi warga sekitar.

- Jalan Setapak

Garis permukiman desa yang dimasukkan kedalam tapak. Untuk membawa keserasian- 
keharmonisan antara proyek dengan kawasan sekitar. yaitu permukiman Desa Glagaharum.

- Genting Tenggelam

Massa bangunan yang dibentuk dengan geometri yang abstrak pada area mengenang dan mengarah tersusun pada area keharmonisan dan membawa pola atap yang sama pada disetiap Unit Kios Kuliner dan Area Kerja. Untuk memunculkan kenangan yang menakutkan dan kesedihan. Kenangan para korban yang rumahnya tenggelam dalam lumpur yang panas.

Desain Skema
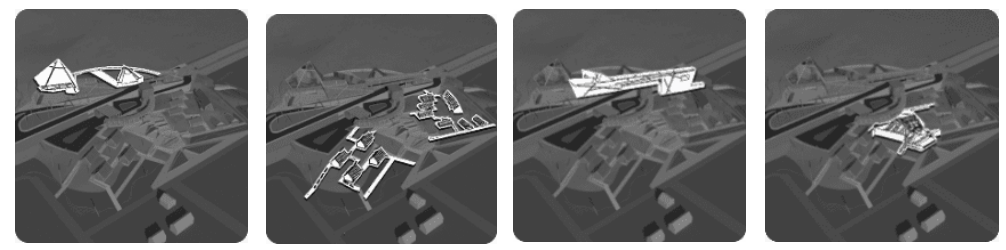

Gambar 17: Desain Skema Mengenang - Unit Warga - Galeri Kios Keramik - Amfiteater

Sumber: Dokumen Penulis, 2021

- Area Mengenang

Ruang-ruang yang membawa pada alur kenangan para korban. Diinterpretasi dari cerita pendek dan Timeline kejadian Lumpur Lapindo.

- Unit Warga

Unit-unit untuk warga mengembangkan ekonominya dan kemampuannya. Sebagai tempat diskusi serta bekerja para warga desa.

- Galeri-Kios Keramik

Ruang para warga desa untuk memamerkan dan menjual hasil karya keramik mereka kepada dunia luar.

- Amfiteater

Amfiteater sebagai tempat untuk mereka berkumpul berbudaya. melaksanakan acara tahunan untuk mengenang Lumpur Lapindo dan acara budaya lainnya.

Sirkulasi dan Zoning

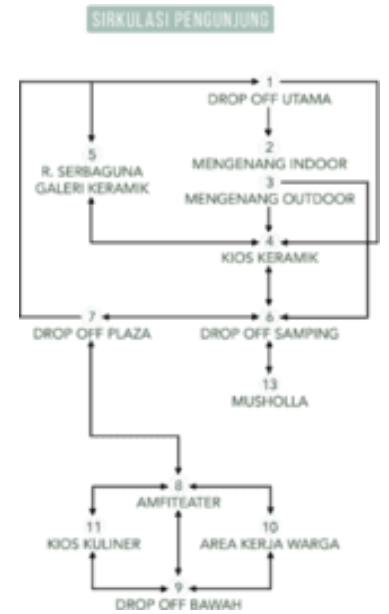

Gambar 18: Sirkulasi Pengunjung

Sumber: Dokumen Penulis, 2021

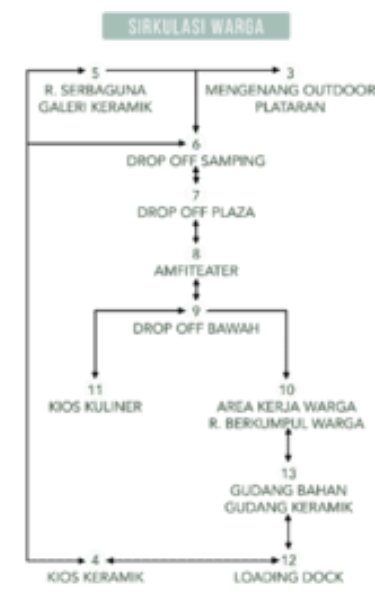

Gambar 19: Sirkulasi Warga

Sumber: Dokumen Penulis, 2021 


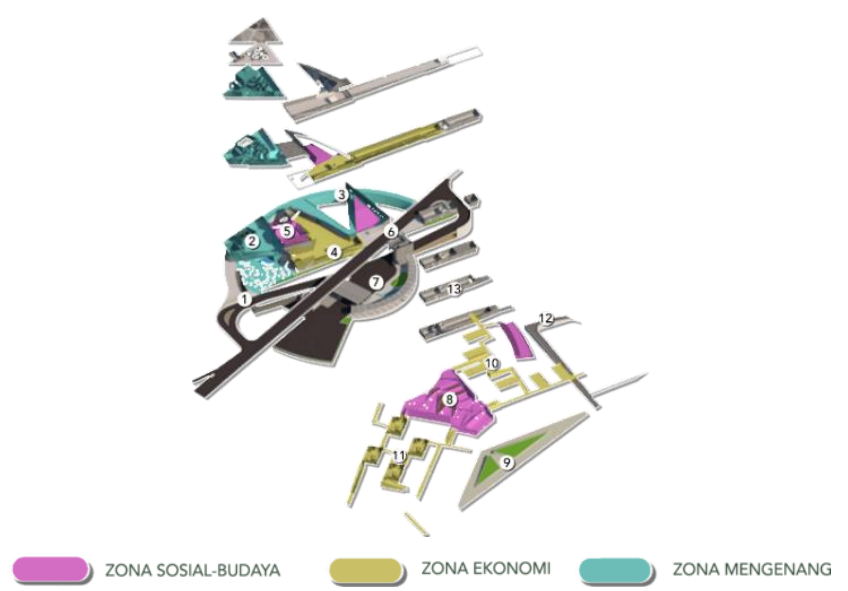

Gambar 20: Diagram Zoning dan Sirkulasi

Sumber: Dokumen Penulis, 2021

Zoning pada kawasan proyek dibagi menjadi 3 yaitu zona mengenang, zona ekonomi dan zona sosial-budaya. Zona sosial-budaya sebagai penghubung antara zona mengenang dan zona ekonomi. Untuk sirkulasi kawasan dibagi kepada 2 jenis pengguna. Yaitu sirkulasi untuk pengunjung dan sirkulasi untuk warga.

\section{Material dan Struktur}

Pada bangunan utama area mengenang memiliki konsep bangunan "Brutalisme Arsitektur" untuk mendukung suasana yang kaku, mencekam dan menegangkan. Menggunakan material dan struktur beton yang dominan pada bangunan.

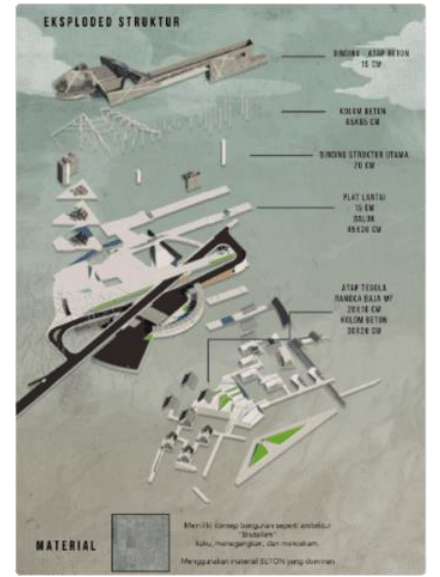

Gambar 21: Eksploded Struktur Sumber: Dokumen Penulis, 2021

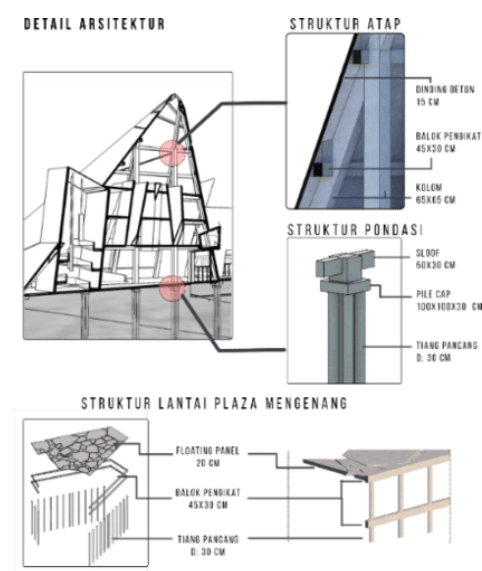

Gambar 22: Detail Struktur Sumber: Dokumen Penulis, 2021

\section{Sistem Plumbing}

Dalam Sistem Plumbing dalam proyek ini memiliki area filtrasi Lumpur Lapindo dan air, karena tapak kawasan proyek berada diatas Lumpur Lapindo dengan jenis lumpur berair. Berikut merupakan diagram sirkulasi sistem plumbing dan sirkulasi alur filtrasi - air bersih - air kotor. 


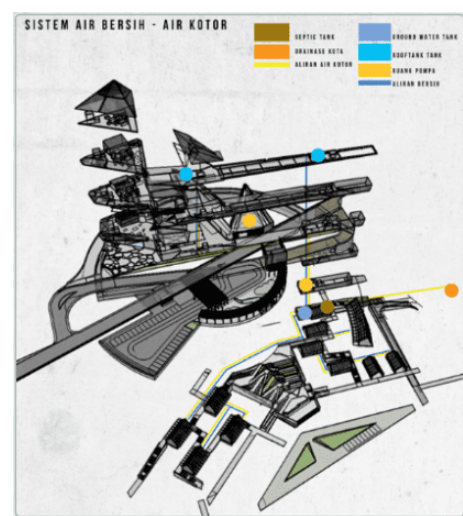

Gambar 23: Sistem Plumbing Sumber: Dokumen Penulis, 2021

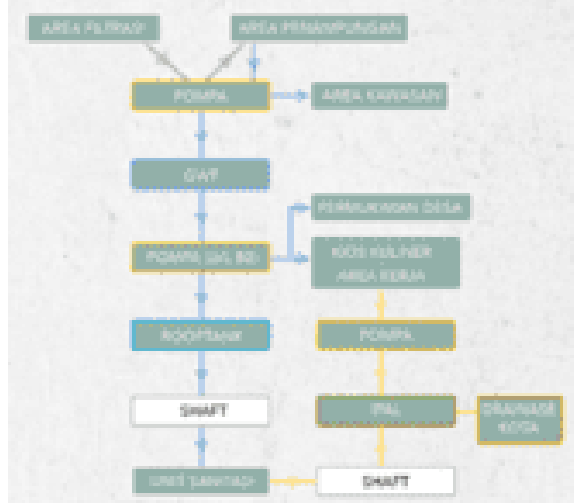

Gambar 24: Sirkulasi Alur Air

Sumber: Dokumen Penulis, 2021

\section{Parameter Melampaui Ekologi (Beyond Ecology)}

Dari 6 parameter Melampaui Ekologi dalam pemaparan kelas 'Dromos Oikos' oleh Agustinus Susanto 2021, pada proyek ini parameter Melampaui yang digunakan ada 4, yaitu:

- Sustainable Digital

Dengan adanya data lingkungan, seperti pemanfaatan lumpur dan lingkungan yang mengalami pencemaran air. Program yang dibentuk dalam proyek adalah pemanfaatan lumpur dan filtrasi air untuk warga sekitar.

\section{- Context}

Pengembalian keharmonisan Sidoarjo dengan mengenang kota mereka yang hilang serta peningkatan ekonomi warga setempat dengan kreatifitas seni keramik.

- Resilience

Membangun kelanjutan kehidupan warga akibat tragedi Lumpur Lapindo dengan memanfaatkan SDA yang ada.

- Adaptation

Membangun masyarakat untuk beradaptasi dengan lingkungan mereka yang bertetangga dengan tanggul Lapindo.

\section{Interior dan Eksterior}

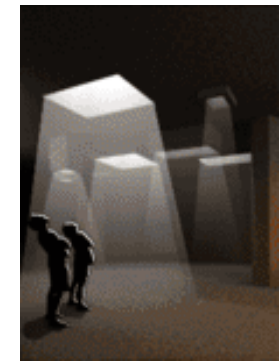

Gambar 19: Atrium

Sumber: Dokumen Penulis, 2021

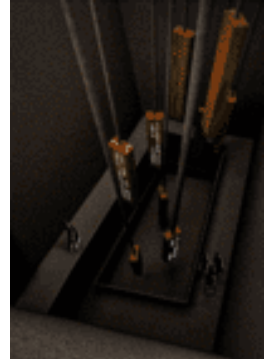

Gambar 20: R. Retorika

Sumber: Dokumen Penulis, 2021 Sumber: Dokumen Penulis, 2021 


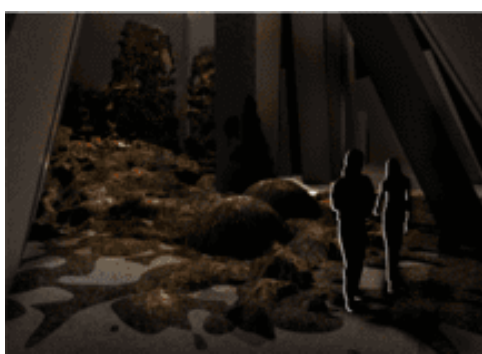

Gambar 22: R. Semburan Sumber: Dokumen Penulis, 2021

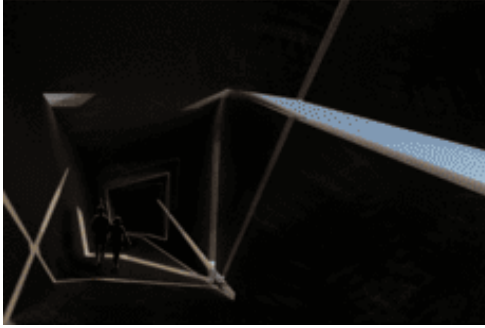

Gambar 24: Ramp Menuju Lvl. 2

Sumber: Dokumen Penulis, 2021

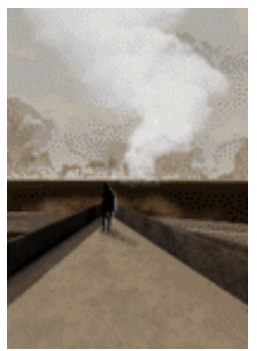

Gambar 25: Plataran

Sumber: Dokumen Penulis, 2021

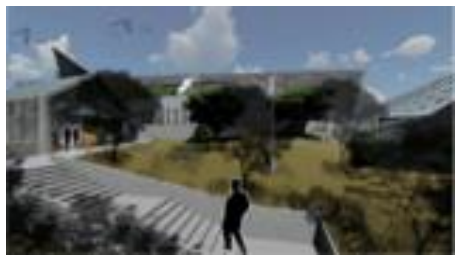

Gambar 28: Unit Kerja Warga

Sumber: Dokumen Penulis,

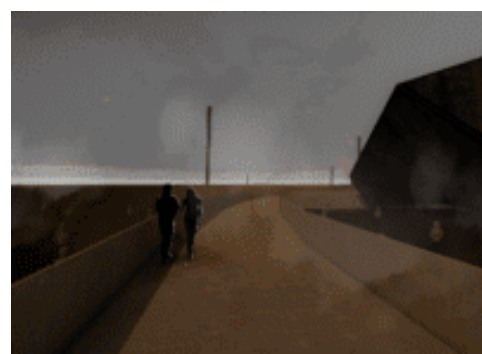

Gambar 23: Kooridor Luar Sumber: Dokumen Penulis, 2021

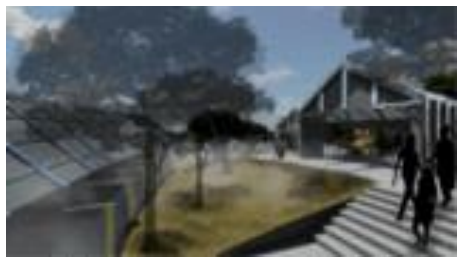

Gambar 26: Unit Kerja Warga

Sumber: Dokumen Penulis, 2021 2021

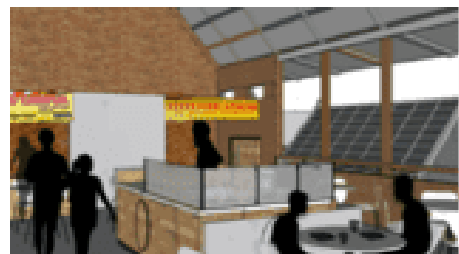

Gambar 27: Unit Kuliner Sumber: Dokumen Penulis, 2021

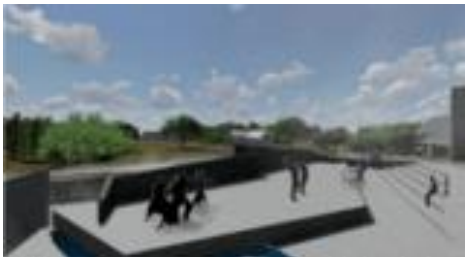

Gambar 29: Amfiteater Sumber: Dokumen Penulis, 2021

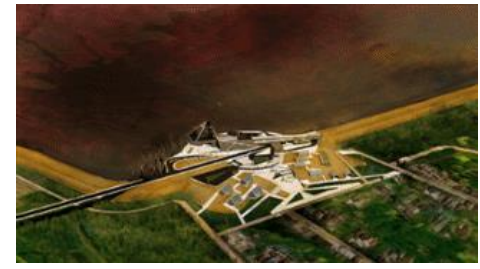

Gambar 30: Bird View 1

Sumber: Dokumen Penulis, 2021

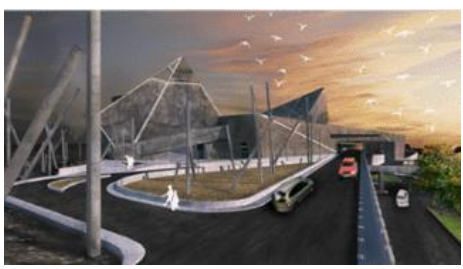

Gambar 32: Area

Mengenang

Sumber: Dokumen Penulis, 2021

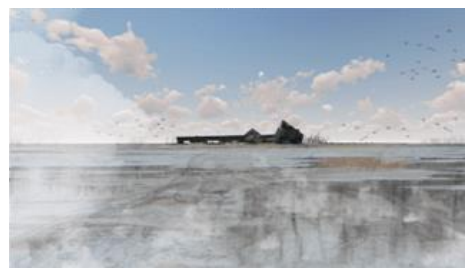

Gambar 31: View Dari Lumpur

Sumber: Dokumen Penulis, 2021

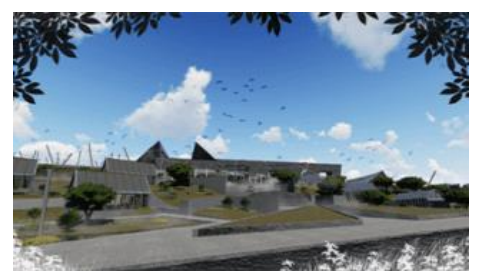

Gambar 33: View dari Jl. Desa

Sumber: Dokumen Penulis, 2021 


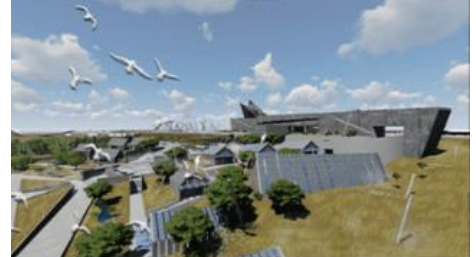

Gambar 34: Bird View Utara

Sumber: Dokumen Penulis, 2021

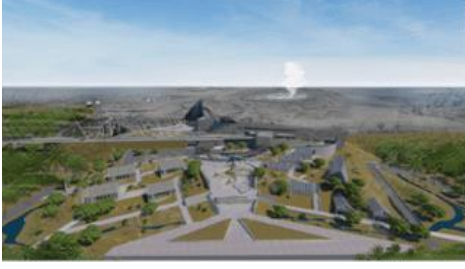

Gambar 35: Bird View Timur

Sumber: Dokumen Penulis, 2021

\section{KESIMPULAN DAN SARAN}

\section{Kesimpulan}

Proyek Mengenang Kota Hilang, Kembalinya Harmoni Glagaharum Sidoarjo berangkat dari sebuah keresahan yang cukup mendunia. Tragedi ini memberikan dampak negatif dari berbagai aspek kehidupan di Sidoarjo. Permasalahan yang terjadi tergambar dalam sebuah cerita pendek karangan R. Griyadi berjudul "Mengenang Kota Hilang", menceritakan pengorbanan para korban yang berusaha untuk mendapatkan kembali hak kehidupannya yang semakin sirna dimata dunia.

Proyek ini disusun untuk menjawab beberapa permasalahan dalam aspek ekonomi, sosial, dan budaya yang hilang dengan memanfaatkan Lumpur Lapindo sebagai sumber mata pencaharian warga setempat. Hal ini termuat dalam program ruang yang tersusun dari metode perancangan yang digunakan yaitu metode narasi yang menghasilkan Area Mengenang dengan suasana alur keruangan ruang yang kaku, gelap dan mencekam mengantarkan cerita pada kenangan atas kejadian bencana Lumpur Lapindo, merasakan dan menyadari kesedihan perjuangan para korban Lumpur Lapindo secara tidak langsung atas hilangnya harmoni kehidupan mereka.

Penggunaan Teori Praktik Sosial yang menghasilkan Area Ekonomi dan Area Sosial-Budaya yang mengedepankan pengolahan limbah Lumpur Lapindo sebagai kerajinan seni keramik, menyediakan area kerja bersama, berdiskusi, dan ruang untuk beraktivitas jual - beli dalam mengedepankan ekonomi masyarakat setempat. dengan Adanya area filtrasi air dan lumpur diharapkan dapat mengurangi pemakaian air lingkungan yang sudah tercemar akibat Lumpur Lapindo. Dengan demikian proyek ini bisa membantu meningkatkan aspek ekonomi dan sosial warga - warga setempat dalam mencapai keharmonisan yang dulu pernah ada. Sehingga, proyek ini hadir sebagai simbol perdamaian dan wajah baru bagi warga setempat yang dapat menutup luka lama mereka.

\section{Saran}

Diharapkan untuk kedepannya para pembaca menyadari tentang permasalahan yang ada dilingkungan sekitar kita, mengingat kembali atas keharmonian yang hilang akibat dari suatu bencana. Dengan adanya keberadaan proyek ini, pembaca dapat mengenang kembali atas kesedihan dan perjuangan para korban Lumpur Lapindo. Mengingat bahwa kelalaian manusia dapat menyebabkan kerusakan lingkungan dan kehidupan yang begitu besar.

\section{REFERENS}

Dinur, B. (2007). What can architecture learn from ecological systems? Interweaving Architecture and Ecology - A Theoretical Perspective, 2.

Frick, H., \& Suskiyatno, F. B. (1998). Dasar-dasar eko-arsitektur : konsep arsitektur berwawasan lingkungan serta kualitas konstruksi dan bahan bangunan untuk rumah sehat dan dampaknya atas kesehatan manusia. Yogyakarta: Kanisius.

Giryadi, R. (2012). Cerita Pendek 'Mengenang Kota Hilang'. Jakarta: Kompas.

Hopkins, S. (1996). On Memory and Architecture. Architecture Thesis Prep.

KBBI Daring. (2016). Dipetik Juni 30, 2021, dari kbbi.kemedikbud.go.id: https://kbbi.kemdikbud.go.id/entri/keharmonian 
Keraf, S. A. (2010). Etika Lingkungan Hidup. Jakarta: Kompas.

Lubis, A. Y. (2014). Postmodernisme: Teori dan Metode. Jakarta: Rajawali Pers.

Maulidina, A. I. (2016). Pendekatan Naratif dalam Perancangan Taman Penitipan Anak. Jurnal Sains.

Mikhael, J. (2018). Surroundings of the West Irian Liberation Monument. Wikipedia: Monumen Pembebasan Irian Barat. Jakarta. Retrieved Juni 30, 2021, from jakarta-tourism.go.id: https://id.wikipedia.org/wiki/Monumen_Pembebasan_Irian_Barat

Mulya, W. N. (2015, Desember 18). Perbedaan, Kesetaraan, dan Harmoni Sosial. Dipetik Juni 30, 2021, dari warung ilmu: blog.unnes.ac.id/warungilmu/2015/12/18/perbedankesetaraan-dan-harmoni-sosial-sosiologi

Qodratilah, M. T. (2011). Kamus bahasa indonesia untuk pelajar. Jakarta: Badan Pengembangan dan Pembinaan Bahasa, Kementerian Pendidikan dan Kebudayaan.

Saraswati, S. (2019). Dunia Posmodern dalam Cerpen "Mengenang Kota Hilang" Karya R. Giryadi. Eufoni.

Sulistiono, R. (2013, Oktober). Etika Lingkungan. Dipetik Februari 2021, dari Etika Lingkungan: http://rovisulistiono.blogspot.com/2013/10/etika-lingkungan.html

Susanto, A. (2021). Dromos Oikos "Melampaui Ekologi". Jakarta.

Wikipedia: Banjir lumpur panas Sidoarjo. (2021, Maret). Retrieved 30 Juni, 2021, from https://id.wikipedia.org: https://id.wikipedia.org/wiki/Banjir_lumpur_panas_Sidoarjo 